\title{
What seals the deal? How compensation and benefits affect women's decisions to accept expatriation in the oil and gas industry
}

\section{Abstract \\ Design/methodology/approach}

A triangulated qualitative research approach draws upon: policy analysis in two oil and gas firms; interviews with two International Assignments Managers in Human Resources; and indepth interviews with 26 female expatriates with experience of a variety of assignment types.

\section{Purpose}

This paper examines how decisions to undertake organisationally-assigned expatriation are influenced by employers' international assignment compensation and benefits policies, seen through the lens of female expatriate breadwinners working in the male-dominated oil and gas exploration and production industry.

\section{Findings}

The paper identifies premiums that uplift salary, housing quality, access to health care, travel and leave arrangements, dual careers and children's education as women's main deal makers.

\section{Research limitations/implications}

Longitudinal studies and comparisons of men's and women's views on policy aspects that support assignment acceptance and cause assignment rejection are needed across a range of industries.

\section{Practical implications}

Housing quality is a key factor in women's assignment acceptance. Good communication prior to expatriation can help build confidence in healthcare provision. Employers should consider how travel and leave policy can be implemented flexibly. Assistance with seeking work visas for partners and coordinating dual career couples' assignments can facilitate female expatriation. 


\section{Originality/value}

This article provides new knowledge on how the content of organisations' international compensation and benefits policies influences female expatriate breadwinners' assignment acceptance set within the theoretical framework of compensating differentials. It proposes a model to depict financial and non-financial deal makers to women's assignment acceptance.

\section{Introduction}

Literature taking us back through three decades indicates that women have been and still are under-represented in expatriation (Adler, 1984; Altman and Shortland, 2008; Brookfield, 2016). It is notable that industries such as engineering, mining and oil exploration which use the largest expatriate volumes remain male-dominated (ORC Worldwide, 2007; Powell et al., 2004; Richardson et al., 2014). Today, women hold a 25\% expatriate share (Brookfield, 2016); but in oil and gas, despite high expatriate volumes (Air Inc., 2016), their percentage representation is at best, only around half of this (Shortland, 2014a). Kanter (1977) suggests that with an average allindustry participation of no more than $25 \%$, women now form part of a 'skewed' population, there being a large preponderance of one type (namely men) over the other (women). But in industries such as oil and gas women expatriates stand out as 'token' breadwinners; with around a $10 \%$ representation, they remain as non-traditional assignees in a male-dominated expatriate environment.

Under the breadwinner model, homemakers (women) engage primarily in domestic labour while breadwinners (men) assume responsibility for primary wage earning, reinforcing patriarchal relations (Crompton, 1999). Although there are some signs of male breadwinner decline, women's entry into male expatriate labour markets such as oil and gas expatriation, remains limited. For example, in Scandinavia - an area of interest for oil and gas given North 
Sea reserves - where the male breadwinner model is weak (Daly, 2000; Millar, 1999), gender inequality is nonetheless in evidence. Higher status occupations such as engineering remain strongly male-dominated while those of lower status (such as laboratory technicians) feminise (Melkas and Anker, 2001). This is of significance to women's expatriation given the oil and gas sector's focus on expatriating engineers (Gordon, 2006).

The literature reports assignment lengths becoming shorter (Morley et al., 2006; Scullion and Brewster, 2001) and organizations making increasing use of 'flexpatriation' including unaccompanied short-term placements, international commuting, rotation and frequent flying (Demel and Mayrhofer, 2010; Mayerhofer et al., 2004; Welch et al., 2007). While available data provide us with women's percentage of total expatriation; we do not know women's share of traditional long-term versus non-traditional alternative assignments. But why do issues concerning women's paucity as expatriate breadwinners or the types of assignments they undertake matter? Given that international experience is a prerequisite to promotions and leadership (Caligiuri and Colakoglu, 2007; Dickmann and Baruch, 2011) this is, in effect, bad news for women's careers.

The expatriate gender diversity gulf is also of serious concern to employers. They face rising demand for international mobility, talent shortages, the need to deploy personnel who add value to their organisations and to produce high return from expatriate investment (Brookfield, 2014; Doherty and Dickmann, 2012; Festing et al., 2013; McNulty et al., 2013). These are outcomes that women expatriates are widely reported to achieve across the world and throughout the decades (Cole and McNulty, 2011; Harrison and Michailova, 2012; Tung, 2004). To understand this tension between women's apparent success as expatriates and their exclusion from international assignments (self- or externally imposed) the extant literature has focused on various reasons why women remain under-represented (Shortland, 2014b). It has examined, for 
example, their willingness and ability to go, host country reception when they are deployed and organisational support available throughout the expatriate cycle including selection, support in post and repatriation. A wide range of issues are identified as contributing and combining to reduce women's likelihood to gain access to expatriate roles (Shortland and Altman, 2011).

Although satisfaction with the compensation package offered on expatriation would be expected to influence assignment acceptance, we have only limited information on the financial elements considered critical such that without them assignees would not go. These are identified as salary, housing allowances, home travel costs, and payments linked to location and for children's education (Warneke and Schneider, 2011). With respect to female assignees, similar financial payments are identified as critical to long-term assignment acceptance: housing, cost of living and children's education allowances, as well as foreign service premiums (Shortland and Perkins, 2016). However to widen our understanding, we also need to know the role that expatriate compensation plays in women's decisions to accept flexpatriate assignments. Knowledge of how non-financial aspects of the international assignment package affect women breadwinners' decisions to undertake long-term expatriation and flexpatriation is also acutely important to our understanding of how expatriate gender diversity can be widened, particularly in masculine industries.

To address these shortcomings, this article specifically examines the views of current female expatriates on the importance that they place on assignment compensation and benefits elements in affirming their decision to go on the assignments offered to them, set within the context of their family situations and their expatriation in the masculine oil and gas sector. It explores which elements 'sealed the deal' and which, had they not been viewed as satisfactory would have jeopardised it, rendered it unacceptable or could do so in relation to future international mobility. Its contribution to knowledge lies in examining women's expatriate 
participation through the lens of female expatriates as breadwinners (Crompton, 1999) and in proposing a model that links women's international assignment compensation and benefits 'deal makers' to assignment types undertaken, set within the theoretical framework of compensating differentials (Anker, 2001; Rosen, 1986).

\section{Literature review}

\section{Definitions and compensation policy context}

Long-term assignments are usually defined as being over a year and immediate family usually go along. Short-term assignments typically last between three and 12 months, are usually unaccompanied and assignment lengths may reflect taxation implications (Shankaran et al., 2011). Commuter assignments involve employees travelling from home to their assignment locations usually weekly or bi-weekly, leaving their families at home. Rotational assignments involve solo travel abroad or offshore to work shifts for regular, set periods followed by rest periods off-shift at home (Collings et al., 2007).

Compensation and benefits arrangements for organisationally-assigned expatriation typically follow one of two main approaches: the going-rate/host country/local market system (assignees gain equity with local host country nationals and other expatriates working in the host location regardless of their home/sending country); and the home-country based 'balance sheet' system (assignees retain equity with home/headquarters peers) (Burnett and von Glinow, 2011; Perkins and Shortland, 2006; Perkins and White, 2009).

The going-rate approach is based upon market pay rates in the host location. This is an attractive proposition if pay rates exceed those in the home/sending country. Yet, it is rare to find expatriates receiving only local terms and conditions. Typically, employers provide additional compensation, for example to assist assignees with children's education costs when local state 
schools are unsuitable, and housing assistance and healthcare may be addressed (Perkins and Shortland, 2006).

The balance sheet is the most commonly used expatriate reward approach (Air Inc., 2016; Perkins and White, 2009). Expatriates maintain their home country standard of living. They are 'kept whole', that is they do not lose out from undertaking their assignment, regardless of whether pay for similar work is lower in the host location. Balance sheet compensation packages that apply to long-term assignments typically comprise: remuneration; allowances; and benefits and insurances (Tornikoski, 2011a). For example, remuneration includes base salary and the premiums linked to this which compensate for hardship and mobility patterns. Allowances refer to payments that address assignees' additional costs (such as pre-assignment home and school search trips, cost of living, housing/utilities, assistance for spouses/partners, children's education, travel and trips home). Other benefits and insurances include employer provision of a car or company housing in place of an allowance, tax/visa assistance, international medical/healthcare and travel insurance cover (Burnett and Von Glinow, 2011; Jenkins, 2014). International assignment policies addressing alternative assignment types typically offer fewer allowances and benefits than are given to those on long-term assignments, frequently reflecting the unaccompanied nature of such international mobility (Cartus, 2014).

\section{Compensating differentials}

Organisationally-assigned expatriation is usually seen as career-enhancing (Caligiuri and Colakoglu, 2007; Dickmann and Baruch, 2011). Flexpatriation has been reported as potentially being even more favourable to career progression than repeated lengthy assignments (Hamori and Koyuncu, 2011). We also know that financial rewards are not considered to be a major expatriation motivator (Pate and Scullion, 2010; Pinto et al., 2012; Suutari et al., 2012;

Tornikoski, 2011b). Rather, expatriates seek return on their investment through undertaking 
international careers (McNulty et al., 2013). Thus, career prospects, skills development, professional challenge, role autonomy and living abroad should all combine to make all types of international assignments attractive (Andersen and Scheuer, 2004; Bonache, 2005; Doherty et al., 2011; Suutari et al., 2012). Taking these factors into account, we might expect competition by workers for expatriate and flexpatriate positions to be high. It therefore appears surprising that organisations give significant additional compensation and benefits to their expatriates and flexpatriates.

However, working in a different geographical area or in a remote, dangerous or unpleasant location, and coping with family separation or upheaval (as are typically experienced with expatriation) suggests a requirement for additional pecuniary or non-pecuniary advantages (Shortland and Perkins, 2016). Indeed, Shaffer et al., (2013: 2971) point out that "employees expect their rewards to match their contributions" and "expatriates sacrifice a lot by relocating and facing challenges in foreign lands". Thus, personal financial impact does feature in influencing assignees' decisions to accept a role abroad (Doherty et al., 2011; Pinto et al., 2012; Suutari et al., 2012; Wagner and Westaby, 2009). If financial elements are unacceptable or are not offered, they can lead to rejection of the package. This can trigger assignment refusal (Suutari and Tornikoski, 2001; Warneke and Schneider, 2011). Hence, the theory of compensating differentials (Rosen, 1986) can help to explain why expatriation and flexpatriation are so well-rewarded financially.

Compensating wage differentials refer to the additional income that is required to be offered to a worker if that person is to accept a job which is considered undesirable relative to other jobs that s/he could perform (Rosen, 1986). As can be seen particularly in the case of longterm assignments, a significant compensating differential applies, being delivered via a wide variety of monetary additions provided to the assignee and family (Perkins and Shortland, 2006). 
Although the balance sheet operates on the principle that assignees are not 'rewarded' for their sojourn abroad, it offers 'compensation' for the various factors that impinge on assignees' home and family life. These additional sources of income, while technically viewed as compensatory actually raise assignees' income levels substantially, potentially making long-term expatriation a very financially rewarding prospect. In industries where expatriate assignments are frequently located in remote, dangerous and hostile places (such as in oil and gas exploration), this compensating differential can be very lucrative indeed.

\section{Female breadwinners and compensating differentials}

Expatriates and their partners consider employer-provided dual career assistance as hugely important and this is one of the main reasons for assignment rejection if not offered (Warneke and Schneider, 2011). International assignment policies are insufficiently rich to reimburse lost spousal income and the practical steps that employers can take to assist dual career couples are limited hindering dual career couples' mobility (Permits Foundation, 2012) particularly for longterm expatriation (Konopaske and Werner, 2005). The problems are exacerbated when male spouses have to adjust to the foreign environment (Punnett et al., 1992) and, in particular, to being secondary breadwinners (Harvey and Wiese, 1998). Being part of a dual career couple correlates with lower expectations of career development for women (Wilton and Purcell, 2010) and career priority is a key predictor of a couple's willingness to accept an assignment (Groeneveld, 2008). Decisions to undertake assignments may thus be taken in favour of the male family member if he holds greater financial power. This is of particular relevance to female expatriate breadwinners as typically they have lower incomes and hold lower family power (Dupuis et al., 2008; Harvey, 1998; van der Velde et al., 2005).

Women state that having children reduces their willingness to accept an international posting (Stroh et al., 2000) with schooling and adjustment being major concerns in developing 
nations or culturally dissimilar countries; those with high school-aged children are particularly reluctant to undertake assignments (Dupuis et al., 2008; Tharenou, 2009). It follows that financial provision for children's education features as one of the top five factors influencing assignees' decisions to accept assignments (Warneke and Schneider, 2011).

Anker (2001: 135) provides us with an insight into how the compensating differentials model can explain women's low representation as expatriates in oil and gas by “casting light on women's preference for certain occupations". Under this model, women 'prefer' occupations with good working conditions (avoiding unpleasant or dangerous jobs) and to enter occupations which are relatively easy to interrupt or combine with childbearing/rearing. The oil and gas industry's 'tough exploration image' with operations depicted in harsh and remote environments does not suggest that women can avail themselves of 'good working conditions'. As such, we might speculate that women may not wish to expatriate in this industry despite its potential for high financial reward either while on assignment and/or later in their careers as a result of gaining international experience.

Anker (2001) further suggests that women 'prefer' good fringe benefits (such as healthcare and crèches), taking some of their 'pay' in non-wage form rather than receiving high monetary reward. This is of particular relevance to expatriation where the reward package typically not only includes premiums that increase basic salary but a range of fringe benefits such as housing, medical care and education assistance for children (Perkins and Shortland, 2006). Expatriates can also usually benefit from a degree of choice or flexibility in their package enabling them to trade pay by spending their allowances on benefits that are of particular relevance to their families (Air Inc., 2016). While the oil and gas industry's image suggests 'tough' working conditions, the sector offers a wide range of fringe benefits (IDS, 2002) and 
provides flexibility in the delivery of expatriate reward through a choice of cash in lieu of benefits-in-kind (Air Inc., 2016) which could be attractive to female expatriate breadwinners.

This research study is important because although international assignment policies appear financially generous, they may not support conditions needed to facilitate female breadwinners. This may potentially help explain women's low expatriate representation. Hence, we might use Anker's (2001) compensating differentials model to examine whether female expatriates and flexpatriates place less emphasis on the financial elements that boost their pay levels on assignment, preferring instead to select fringe benefits that improve their home and family life while abroad. This information could assist organisations to design international reward policies that are attractive to women, thereby contributing to increasing expatriate gender diversity.

Set within the oil and gas exploration and production sector and framed theoretically by compensating differentials as applied to women's work (Anker, 2001), this research study therefore sets out to address the following research questions:

- Which compensation and benefits elements within organisations' international assignment policies do female expatriate/flexpatriate breadwinners value?

- Of the elements that these women regard as being most important, which seal the deal when they are offered different types of international assignments?

\section{Method}

Members of the UK oil and gas industry peer group were contacted and a presentation given to HR representatives with responsibility for international assignments in 18 member firms to enlist support for a research project into women's expatriate participation. This qualitative research on compensation and benefits was part of the wider study looking into how organisational policies 
were implemented in the oil and gas exploration and production sector so as to address aspects of the 'expatriate cycle', following Mayrhofer and Scullion's (2002) findings highlighting the difficulties that women face at each stage of this cycle.

Two medium-sized oil and gas exploration and production organisations headquartered in North America and Western Europe agreed to take part. The case study firms' operations spanned between 20-30 worldwide locations. Company A employed 12,000 people of whom 3\% were expatriates ( $8 \%$ female: 27 women). Company B employed 6,000 people of whom $10 \%$ were expatriates (11\% female: 66 women). Both firms agreed to provide access to their HR teams and to all 93 female expatriates. All of the female expatriates were currently on assignment and worked full-time. Access to host country line managers and male expatriates was not granted given resource and time constraints but this was not a problem as the research focus was on women's experiences.

The research approach involved triangulation of the analysis of the financial and nonfinancial elements within international assignment policies applicable to different lengths and patterns of international mobility, with interview data from the International Assignments (IA) Manager in each firm who held responsibility for designing and implementing these, and with interview data from 26 female expatriates. The international assignment policies from both firms were summarised and tabulated to compare the compensation and benefits elements available to those undertaking long-term, short-term, rotation and commuter assignments. Both firms had relatively comparable provision and the IA Manager interviews indicated that they operated similar implementation practices.

Of the 93 female expatriates, 55 volunteered to be interviewed (11 in Company A and 44 in Company B), of whom 26 were selected (eight from Company A; 16 from Company B) using stratified sampling (Collis and Hussey, 2009) to ensure appropriate representation of expatriate 
experience by assignment length and pattern, assignment region, and family status (Table 1). Although the assignee and interviewee profile reflected predominantly long-term expatriation, the stratified sampling took care to ensure women with previous experience of other assignment types within their current firm were included so as to gain more in-depth understanding of issues related to alternative flexpatriate assignment types. For example, five women had either current or previous rotational assignment experience; and six women had either current or previous short-term assignment experience. Although none were currently undertaking commuter assignments, one interviewee had done so previously with her current firm. The interviews provided rich data to explain the effect of compensation and benefits on women's assignment participation decisions set within their family context. To preserve confidentiality, their names, actual home/host countries and personal data are not revealed.

- Table 1 -

The interviews aimed to find out which elements of the compensation and benefits policy 'seal the deal' when women are offered different types of expatriate assignments. These were semi-structured and were conducted either face-to-face in the UK or by telephone with those abroad in a private setting. The interviews conducted with the IA Managers lasted 90 minutes and focused on changes and developments in policy and how policy was applied to various assignment types, with examples. The interviews with female assignees were conducted separately and lasted between 60-90 minutes. The assignees were all supported by their organisation's international assignment policy appropriate to their assignment type. They were asked how well the expatriation process had worked and to give examples, and what they saw as the key elements in the international assignment package which encouraged or negated their expatriate/flexpatriate participation. 
The interviews were taped and transcribed, and the qualitative data were coded and analysed using NVivo 8. This formed the underpinning to a template analysis (King, 2004), with the coding trees representing not only policy elements already identified from the policy analysis but also emerging issues. Coding trees enabled the researcher to link inter-related ideas, quantify the prevalence of an issue and ensure representative illustrative quotations.

\section{Findings}

In this section data are presented aligned to the compensation and benefits policy elements identified by the women assignees as being of greatest importance to them. First, the key policy elements available are identified. How these are implemented, as described by the IA Managers, are reported next. Any differences in levels of importance attached to the policy components reported by the assignees by assignment type are noted. The female assignees' views on which elements seal the deal (or potentially could have caused them to refuse their assignments) are then presented. Finally, the implications of each of the findings in relation to Anker's (2001) compensating differentials model are given.

By way of background, both organisations used a home-based balance sheet approach with a wide variety of allowances and benefits given to their long-term assignees. Less generous variations of this approach applied to short-term and rotational assignments, frequently reflecting their unaccompanied status. Commuter assignments received only limited support over and above home-based terms and conditions (such as local housing/transport; and flights to/from).

\section{Housing}

Both firms offered free rented accommodation in the host country for all assignment types subject to local rental limits. The HR representatives explained that assignees on long-term assignments typically rented out their home country property; they lived rent-free abroad and 
covered their housing costs at home. This provided significant financial incentive to go on a long-term assignment.

Housing was indeed one of the most frequently cited factors deemed as very important to assignment acceptance by all assignees. Unexpectedly though, the assignees interviewed did not focus on the monetary value of the allowances given (even though this had been stressed by the IA Managers), rather they highlighted that it was the quality of housing that was key to their acceptance of long-term assignments. They identified this very clearly as the main likely deal breaker if their expectations were not addressed. This was the case regardless of marital, family or un/accompanied status with similar views expressed by women assignees across the world regardless of location:

"I didn't want to leave ... my nice home to come here to live in a closet because I know how expensive things are here. I wouldn't have been happy living in a little tiny room with no light ... so the Company helped me to get a decent flat so that was very important to me ... Yes, the housing element was the key thing.” (\#69, long-term; previous rotational)

"We like to be flexible, but it was almost (the) deal-breaker. We went out on a look-see but what they were showing us, at one point I turned to my husband and said if this is the quality of the housing I'm not coming. And I'm not a prima donna, by any stretch, but I'm not coming back to a place like this at the end of a long working day, there is no way..." (\#14, long-term)

"I think ... when you turn up somewhere, it's the big things that count. It's the housing ... If the family are happy, then you are happy at work. It is the classic. It is worth putting the time and effort in getting your house sorted ... The problems arise when you're not happy at home.” (\#2, long-term)

The firms' policies indicated that help with home search and leasing property was given to those on long-term assignments; this was available to short-term assignees as well if they had to arrange their own accommodation. The IA Managers noted that specialist local agents were 
employed to carry this out so expatriates did not have to be concerned over the legalities of renting property, which could be a particular obstacle if they did not speak the local language. Women placed high importance on this benefit:

"If I would have had to have organised my own accommodation over there, it is enough really organising it here, organising your lease to come to an end at a suitable point, finding different accommodation for the other partner while you are away and then sorting out for your return is enough without having to do it in another country as well. That would have been too much.” (\#3, short-term)

"There is only one I think, and that is support for housing. If it is giving you a bundle of money or finding a home for you, it is definitely that, nothing else, I think. Obviously you need to have the salary and benefits commensurate with your expat posting. But physically it is the (support for) housing." (\#39, long-term) With respect to rotation and commuter assignments, and the majority of short-term assignments, the assignees reported that individuals were usually allocated somewhere to live and could take only limited possessions with them: “On rotation you live in a room, you don't take your stuff out there, so you just live in a room like Butlins". They frequently expressed disappointment in their housing quality: "I should have seen the accommodation beforehand”. This impacted on their overall assignment satisfaction:

“...you are taken to a guest house where people can stay. The guesthouse was pretty horrible. Again, it is pretty horrible if you are a woman, because you are the woman, and 15 bored men in a small hotel. I ended up, I have some friends who moved out there and they had an apartment and they let me stay with them and that was really the only reason it was bearable.” (\#33, long-term; previous commuter)

Nonetheless, given the short periods away from home on these flexpatriate assignments, they did not report housing quality as a potential deal maker or breaker.

These findings add to our knowledge as they indicate that women's focus is not on the monetary reward given for housing but on having pleasant, comfortable conditions that help 
create a sense of home, regardless of family circumstances. This aligns with Anker's (2001) compensating differentials model predicting women's preference for good fringe benefits.

\section{Remuneration, premiums and allowances}

In addition to home-based salary, pension continuity, bonuses and stocks and shares, both firms provided a variety of premiums and allowances linked to undertaking long-term, short-term and rotation assignments. The HR experts reported that hardship locations attracted very high foreign service premiums (FSPs), paid as a monthly uplift to salary. For instance, FSPs of 50\%-60\% of salary applied in certain African locations. All financial elements were considered to be very important by the women assignees' to their assignment acceptance but in particular the FSP, the car allowance, the rotation allowance and the cost of living allowance (COLA) stood out. Premiums and allowances that raised basic salaries acted as both as incentives to go and also as potential deal breakers if they were not offered. Women with children saw the financial aspects as "accruing a future for my family" and those with partners looked to "the package" to provide some form of compensation for reduction in spousal careers/income.

FSPs were considered to be important by both long-term and short-term assignees to provide compensation for tough living conditions:

\footnotetext{
"I hate to say that money sort of makes up for it, and it doesn't in many ways, but the uplift, it makes you feel a little bit better about being here. Healthcare here is very limited ... so I do get a very good uplift, and I tell people that uplift really for me ... Not that the money would make up for your health, but I think it would be tough if they told me to come here and I didn't have a good foreign service premium.” (\#57, long-term)
}

Even in locations where lower premiums applied, such as Australasia, this financial incentive was still regarded as important.

Rotational workers received a rotation allowance that provided an uplift to salary and this was viewed as a "bonus" necessary to assignment acceptance: 
"I would say the bonus, the bonus I would say is excellent ... If I had to work for a company that didn't

offer me any compensation, monetary compensation, I wouldn't go.” (\#59, rotational)

Commuter assignments that did not attract such payments were unpopular or refused:

“... for someone who spent a quarter to a third of their time out, it was a bit unreasonable to get no uplift or support at all, particularly when other individuals did ... I think that it has to ... add up to something that is financially beneficial” (\#33, long-term; previous commuter)

“There aren't that many job opportunities but that would not be something that I would choose at the top of my list at all." (\#35, long-term)

COLA was based upon the cost of living differential between the sending and receiving country and was crucial when relocation involved moving to higher cost areas, especially when undertaking long-term assignments. The provision of a car was also deemed critical to assignment acceptance by assignees on all assignment types. Cars - although standard in policy - were considered of greatest importance in "car culture” locations (North America, in particular). Assignees indicated that if they had to meet additional living costs without compensation or were not given a car, these factors may influence their decision to go negatively:

"The foreign service allowance, the living allowance for the assignment location, because I need to make sure that I can live with that amount of that money that I'm going to get ... Without a living allowance, an apartment allowance, a car allowance, I may not decide to move.” (\#65, long-term)

'It all depends on the location but having been over there, if you didn't have a car that would have been a bit of a nightmare. And you would have to have paid for one yourself really.” (\#3, short-term)

“...my first assignment was six months in a shared house with no car and no driver ... So the (long-term) policy has definitely improved...." (\#24, long-term; previous short-term) 
These findings add to our knowledge by indicating that certain monetary rewards do encourage women to accept all types of assignments. This suggests some contradiction to Anker's (2001) model relating to women's preferences.

\section{Medical}

Medical insurance was covered in policy and was identified as very important to assignment acceptance, particularly by those on long-term assignments. The key worry for the interviewees concerned the practicalities of healthcare provision in-country, particularly in non-Western destinations. Women were anxious about access to reputable clinics with doctors who spoke their language, especially in relation to women's health (screening, gynaecological and pregnancy conditions). The potential deal breaker though concerned children's health; assignments in locations with medical facilities considered unsuitable were rejected:

"It (Central Asia) is not my first choice of location as a place to live with a family, because the medical facilities are arguably not good enough with children so that is a big kind of no, no really." (\#35, long-term)

These findings are of interest because they show it is the practical, on-the-ground provision of healthcare for themselves and their families that is important to women, rather than the financial aspects of medical insurances. Many of the destinations in the oil and gas exploration and production industry are remote and/or newly industrialising countries with security and safety concerns. Assignees' worries over medical care, particularly for their children, thus reflect Anker's (2001) model which predicts that women seek good fringe benefits that address family concerns as part of their assignment acceptance decision-making process.

\section{Travel and leave}

Policies covered air fares to/from the assignment location. Vacation travel allowances for longterm assignments were paid once a year; short-term assignees received one trip home, depending on assignment length. Company B paid for quarterly trips home for unaccompanied long- and 
short-term postings. The main theme that emerged from the IA Managers concerned the significance of policy provision to enable unaccompanied assignees to return home regularly. They explained that it was particularly common in the sector for men to leave their wives/partners behind looking after children. To encourage assignees (men and women) to undertake unaccompanied expatriation, travel policy was applied flexibly where practicable: cash might be given rather than tickets to facilitate more frequent trips and/or family members could fly out if the assignee was constrained by work duties.

It was notable that all of the women considered travel and leave to be very important to assignment acceptance. Assignees valued all trips home. They also said that rest and recreation was important in addition, if they were to accept an assignment in a challenging location. The interviewees liked practice that funded multiple tickets to reunite families. One woman had eldercare responsibilities and noted that she could make use of cash allowances to fund several trips home economy class, preferring this to one business class trip from the opposite side of the world. The unaccompanied married/partnered assignees reported that this was a particularly important gesture, demonstrating to local management that the headquarters personnel understood the difficulties lone women faced on assignment:

“... the company paying for those trips ... in managers' mind-sets, it makes them think 'this is actually kind of hard for (me), she is away from her family and she is here on her own ... I will be flexible around her needs as to when she needs to go home'. It identifies it as an issue. The company ... helps single people to manage that balance between taking the career opportunities and ... keeping in touch with the people that they care about at home ... I think that is very important.” (\#10, long-term; previous short-term) However, the unaccompanied female assignees who had left spouses/partners at home sought even greater flexibility; they suggested that local host country public holidays could be worked abroad and be traded for longer home leave. Spending time with their partners at home 
was identified by the interviewees as a potential deal breaker when women undertook unaccompanied long-term assignments:

“... that is one of my issues, the whole flexibility thing really, these trips ... when I went out there I said 'about four trips home ... God, that is only every three months I can stay with my husband' ... and I was told by the guy who wanted me to go out there 'look ... you get back to (home country) three or four times a year on business, and then ... you can stay over the weekend and see your husband or work in (home office) or work from your home for a couple of days' and ... that was great, and that really did work ... but because of the cost cuts, I haven't had a business trip since ...” (\#50, long-term)

These findings add to our knowledge by highlighting the difficulties that women experience taking unaccompanied assignments and the high value that they place on travel home to maintain family relationships. This finding aligns with Anker's (2001) model in showing that women assignees seek flexibility in the provision of fringe benefits to address family issues, especially when their working conditions engender family separation.

\section{Dual careers and children's education}

Help with obtaining spouse work visas was addressed in policy. An annual spouse/partner allowance was available to long-term expatriates; Company B extended this to other assignment types (excluding rotation). The IA Managers noted partner allowances were too low to compensate for the loss of a second income. While company policy was very limited in respect of providing financial recompense, they noted that organisational practice did major on coordinating international mobility so that couples could relocate together and maintain employment as far as was practicable.

Assignees commented on the high importance of obtaining spouse work visas, with some noting them as "THE deciding factor". Despite visas being addressed in policy, the more common theme was that dual career couples received too little help with finding suitable work opportunities for their partners: 
“In (host country), my husband couldn't work because he wasn't able to get a work permit ... he found that very frustrating ... But even in countries where it is possible to work, the company don't provide any support in helping somebody to do that.” (\#46, long-term; previous short-term)

The spouse/partner allowance was seen as a welcome, but 'token' gesture; not as a 'make or break' factor resulting in assignment acceptance:

"I think that the spousal allowance is nice, but it isn't something that would make you not go on the assignment, but I think it is very important that they offer that, because it is the recognition of what you might be giving up and for them to retain their skills." (\#56, long-term)

The assignees said that, unless both partners could work abroad, expatriation represented a pay cut for the family. They called for more support to mitigate the loss of the second income, ideally through partner employment but otherwise via financial compensation:

“... because their partners have a job and that is paid at the same amount or more, that could be a large part of the reason why women don't go abroad, because ... despite paying for your accommodation and your expat uplift, the family takes a pay cut. So if you are further putting into that about school fees, or you have got a cap on how much accommodation (the Company is) going to pay for ... arguably, you are going to have fewer females going abroad because the issue is that the family takes a pay cut to do so." (\#35, longterm)

The firms' policies provided education payments for legally dependent children in the host location for long-term assignments. Company B extended this to accompanied short-term assignees. The IA Managers understood the high importance assignees placed on payment of school fees abroad and education assistance on repatriation. Although relatively few women received this, all who did said that it was very important. Mothers and non-mothers were highly aware of the value of educational support in enabling the international mobility of families. One woman described herself and her expatriate mother colleagues as "particularly vociferous" when reductions in school fees were proposed. The interview data revealed that once women had children, the payment of education fees became a potential deal breaker: 
“... looking forward, I would say the schooling $\ldots$ because being on an international assignment you have to put your kids into international schools, and you have to pay for it. But I wouldn't have said that this time last year, but now I have got a child ... it is starting to become important to me.” (\#60, long-term) These findings reaffirm our knowledge of the impact of dual careers and children's education on women's willingness to undertake expatriation. The requirement for policy to address financial issues such as loss of spousal/partner income and education costs indicates the level of emphasis female expatriate breadwinners place on monetary reward, as well as benefits that address practical assistance, contrasting to some extent with Anker's (2001) model.

\section{Discussion}

This article examines female expatriate breadwinners' views on how their organisations' expatriate compensation and benefits packages support them and their families, and influence their decisions to undertake a variety of assignment types. It thus takes a fresh look at women's expatriation by considering a number of non-traditional avenues. First, expatriate compensation and benefits are relatively under-researched and theorised academically (Harvey and Moeller, 2009; Yanadori, 2011). Second, we know very little about women's participation in flexpatriation. These findings provide us with new understandings through a female breadwinner lens (Crompton, 1999). Women take into account both quantitative and qualitative aspects of their employers' international assignment packages, assessing assignment implications for themselves and for their families. Mothers see expatriation as accruing a future for their children; married/partnered women look to the generosity of the overall package to provide compensation for reduction in spousal careers/income. Hence, financial deal makers include basic salary and salary uplifts as well as spouse/partner employment income and children's education fees. However, qualitative issues such as housing quality, family reunion and health are also of high importance to female assignees' assignment acceptance. 
The emphasis that the female expatriate breadwinner places on these issues is linked to her assignment type and family situation as shown in the model predicting likely deal makers (Figure 1). This model shows that direct financial compensation is of high importance to all female assignees, regardless of assignment type and marital/family status. Employment assistance for spouses/partners is of high importance to married/partnered women accompanied on long-term assignments. Children's education fees are critical to women with dependent children on accompanied long-term assignments. All assignees on long-term assignments are concerned that housing quality is addressed. Married/partnered women on unaccompanied longterm assignments seek home leave travel to address family reunion. Host country medical care is of greatest concern to women who take their children with them on long-term assignments.

Examining this theoretically in the context of compensating differentials as specifically related to women's work, the deal makers identified here indicate only partial support for existing theory which proposes that women are more likely to 'prefer' occupations with good fringe benefits and to take some of their 'pay' in non-wage form rather than receiving high monetary reward (Anker, 2001). This research, as summarised in Figure 1, shows that female expatriates value fringe benefits that address issues such as housing quality, in maintaining family relationships when they are on unaccompanied assignments, and via their emphasis on ensuring their children's health while abroad. However, a contrast to theory is also identified: high monetary reward also underpins women's assignment acceptance and must be addressed appropriately by sending employers. This suggests that refinement of Anker's (2001) model is needed to reflect the emphasis women place on a mix of financial and non-financial aspects of support when they undertake expatriation and flexpatriation.

An assignment type effect is also identified by this study and this also needs to be taken into account in predicting female breadwinners' reward preferences in the context of 
expatriation. Long-term assignments provide the best outcomes for reward and good fringe benefits (and are the most frequently undertaken assignment type); short-term and rotational assignments tend to be well-rewarded but organisational policy places less emphasis on fringe benefits (and fewer women undertake these assignment types); commuter assignments provide the least attractive outcomes on both fronts (and very few women undertake them).

- Figure 1 here -

\section{Implications for practice}

Women's assignment acceptance rests on being able to find 'pleasant', not excessive or exorbitant housing, that helps them build a sense of 'home'. Home search and assistance with securing leases make a clear difference to women's assignment satisfaction. Employers might therefore place increased emphasis on assistance to aid the identification of suitable quality housing, consider the timing of assignments such that quality accommodation can be secured, and ensure that this support is offered to short- as well as long-term assignees. Access to appropriate healthcare may be difficult to guarantee in remote and underdeveloped locations but employers should liaise with medical care providers to identify appropriate facilities and devise logistics to enable access to them. Good communication prior to expatriation can help build confidence in healthcare provision. Employers should consider how travel and leave policy can be implemented flexibly. Arrangements to enable assignees to carry out defined periods of work in their home country linked to home leave or business travel could be formalised via policy.

One of the most important deal makers is the monetary uplift to salary made via payment of premiums and allowances. Assignments that did not attract these payments, most notably commuter assignments, were not seen as being sufficiently financially attractive. Other factors such as the requirement for frequent travel and consequent disruption to family life also affect decisions to undertake such forms of international mobility. Employers may wish to introduce 
premiums for those commuting to (but not residing in) host locations. Employers cannot compensate for lost spousal income given the expense involved but assistance with seeking work visas for partners and coordinating dual career couples' assignments are likely to be useful interventions to facilitate female expatriation. Employers should be wary of reducing children's education allowances as this is a sensitive issue and a potential deal breaker.

\section{Research limitations and future directions}

As policy design and implementation may differ across industries and by company size, further research is needed to explore any sector/size/historical differences in the content and delivery of international assignment policies and their effects on women's assignment acceptance. The methodology used here involved a cross-sectional design but this provided only a snapshot of female expatriates' views on the importance of financial assistance to their participation decision. A rigorous academic longitudinal study to examine the effects of reductions in specific elements of compensation and benefits on female breadwinners' decisions to undertake expatriation and flexpatriation would be therefore helpful. The complex relationships between work and family (Lazarova et al., 2010) also require further consideration.

This study also did not address whether future compensation was a factor in assignment acceptance decisions. The career benefits that flow from expatriation and the potential for future earning potential from gaining such experience require further study. For instance, whether women should accept international commuting to further their careers and future income, even if this means frequent travel, family disruption and accepting lower levels of compensation and benefits than on long-term expatriation, would be a valuable line of enquiry.

A comparative study that specifically addresses men's and women's views on the importance of the financial aspects of expatriate policy content and their influence on assignment acceptance is needed. Such research should address a range of different assignment types. This 
study identifies the issues that women say could prevent them from going on an assignment; it does not actually cross-check these with the factors that have actually resulted in assignment refusal. It would therefore be valuable to explore the opinions of men and women who have rejected different types of assignments to find out which elements of the policy actually acted as deal breakers.

\section{Conclusions}

This article examines female breadwinner expatriation in a non-traditional context. It provides us with new knowledge on how the content of organisations' international compensation and benefits policies influences female expatriate breadwinners' assignment acceptance set within the theoretical framework of compensating differentials. It proposes a model to depict financial and non-financial deal makers to women's assignment acceptance. In terms of reward, premiums and allowances that uplift salaries, cars, enabling partners to find paid employment, and meeting children's international school fees are the key deal makers and must be provided by their employers. In relation to good fringe benefits, women insist on quality housing, access to healthcare that addresses in particular their children's health, and travel arrangements to maintain home country family relationships.

An assignment type effect is also identified. Women going on long-term assignments have the most to gain financially and this may serve to reinforce these as their preferred assignment type. That said, once they marry, are partnered, and/or have dependent children, these demographics will affect women's long-term assignment acceptance unless specific rewards and fringe benefits relevant to these family ties are addressed. Rotational, short-term and commuter assignments are unaccompanied and are less well supported through organisational policy, potentially reinforcing these as less attractive. As the use of long-term expatriate 
assignments declines in favour of these assignment types, this is potentially detrimental to women's future willingness to undertake expatriation. Whether women will need to consider undertaking less well-remunerated and potentially more disruptive assignment types to gain international experience and/or the extent to which organisations will need to alter their compensation and benefits policy and practice to make alternative assignments more attractive is currently unknown. Nonetheless, this research provides a first step in understanding how compensation and benefits might help to explain - and how employers might address - women's continuing low share of expatriation.

\section{References}

Adler, N.J. (1984), "Women in international management: Where are they?", California Management Review, Vol. 26 No. 4, pp. 78-89.

Air Inc. (2016), Mobility Outlook Survey, Air Inc, Cambridge, MA.

Altman, Y. and Shortland, S. (2008), "Women and international assignments: Taking stock - a 25 year review", Human Resource Management, Vol. 47 No. 2, pp. 199-216.

Andersen, T. and Scheuer, S. (2004), “Attitudes toward foreign assignments among Danish economists", Thunderbird International Business Review, Vol. 46 No. 6, pp. 725-741.

Anker, R. (2001), “Theories of occupational segregation by sex: an overview”, in Loutfi, M.F. (Ed.), Women, Gender and Work: What is Equality and How Do We Get There?, International Labour Organization, Geneva, pp. 129-155.

Bonache, J. (2005), “Job satisfaction among expatriates, repatriates and domestic employees: The perceived impact of international assignments on work-related variables", Personnel Review, Vol. 34 No. 1, pp. 110-124. 
Brookfield. (2014), Global Relocation Trends: 2014 Survey Report, Brookfield Global Relocation Services, Chicago, IL.

Brookfield. (2016), Global Mobility Trends Survey, Brookfield Global Relocation Services, Chicago, IL.

Burnett, M. and Von Glinow, M.A. (2011), "Total rewards in the international context", in Harzing, A.-W. and Pinnington, A.H. (Eds.), International Human Resource Management, Sage, London, pp. 468-503.

Caligiuri, P.M. and Colakoglu, S. (2007), “A strategic contingency approach to expatriate assignment management”, Human Resource Management Journal, Vol. 17 No. 4, pp. 393-410.

Cartus. (2014), Global Mobility Policy and Practices 2014 Survey Report: Trends in Global Relocation, Cartus, Danbury, CT.

Cole, N. and McNulty, Y. (2011), "Why do female expatriates "fit-in" better than males? An analysis of self-transcendence and socio-cultural adjustment", Cross Cultural Management: An International Journal, Vol. 18 No. 2, pp. 144-164.

Collings, D.G., Scullion, H. and Morley, M.J. (2007), “Changing patterns of global staffing in the multinational enterprise: Challenges to the conventional expatriate assignment and emerging alternatives", Journal of World Business, Vol. 42 No. 2, pp. 198-213.

Collis, J. and Hussey, R. (2009), Business Research: A Practical Guide for Undergraduate and Postgraduate Students, Palgrave Macmillan, Basingstoke.

Crompton, R. (1999), “The decline of the male breadwinner: Explanations and interpretations", in Crompton, R. (Ed.), Restructuring Gender Relations and Employment: The Decline of the Male Breadwinner, Oxford University Press, Oxford, pp. 1-25.

Daly, M. (2000), The Gender Division of Welfare, Cambridge University Press, Cambridge. 
Demel, B. and Mayrhofer, W. (2010), "Frequent business travellers across Europe: Career aspirations and implications", Thunderbird International Business Review, Vol. 52 No. 4, pp. 301-311.

Dickmann, M. and Baruch, Y. (2011), Global Careers, Routledge, Abingdon.

Doherty, N.T. and Dickmann, M. (2012), "Measuring the return on investment in international assignments: An action research approach", The International Journal of Human Resource Management, Vol. 23 No. 16, pp. 3434-3454.

Doherty, N., Dickmann, M. and Mills, T. (2011), "Exploring the motives of companybacked and self-initiated expatriates", The International Journal of Human Resource Management, Vol. 22 No. 3, pp. 595-611.

Dupuis, M.-J., Haines III, V.Y., and Saba, T. (2008). 'Gender, family ties, and international mobility: Cultural distance matters'. The International Journal of Human Resource Management, Vol. 19 No. 2, pp. 274-295.

Festing, M., Budhwar, P.S., Cascio, W., Dowling, P.J. and Scullion, H. (2013), “Current issues in international HRM: Alternative forms of assignments, careers and talent management in a global context”, Zeitschrift für Personalforschung, Vol. 27 No. 3, pp. 161-166.

Gordon, G. (2006), “Managing expatriate careers”, working paper, Managing expatriates and globally mobile employees, Taylor and Francis Events, London, September, 2006.

Groeneveld, S. (2008), “Dual careers and diplomacy”, Review of Public Personnel Administration, Vol. 28 No. 1, pp. 20-43.

Hamori, M. and Koyuncu, B. (2011), “Career advancement in large organizations in Europe and the United States: Do international assignments add value?", The International Journal of Human Resource Management, Vol. 22 No. 4, pp. 843-862. 
Harrison, E.C. and Michailova, S. (2012), "Working in the Middle East: Western female expatriates' experiences in the United Arab Emirates", The International Journal of Human Resource Management, Vol. 23 No. 4, pp. 625-644.

Harvey, M. (1998), "Dual career couples during international relocation: The trailing spouse", The International Journal of Human Resource Management, Vol. 9 No. 2, pp. 309-331.

Harvey, M. and Moeller, M. (2009), "Expatriate managers: A historical review”, International Journal of Management Reviews, Vol. 11 No. 3, pp. 275-296.

Harvey, M. and Wiese, D. (1998), “The dual-career couple: Female expatriates and male trailing spouses", Thunderbird International Business Review, Vol. 40 No. 4, pp. 359-388.

IDS. (2002), International Assignments, IDS Studies, No. 728 (May), Incomes Data Services Ltd, London.

Jenkins, G. (2014), “International reward”, in Özbilgin, M.F., Groutsis, D. and Harvey, W.S. (Eds.), International Human Resource Management, Cambridge University Press, Melbourne, pp.108-127.

Kanter, R.M. (1977), Men and Women of the Corporation, New York, NY, Basic Books. King, N. (2004), "Using templates in the thematic analysis of text", in Cassell, C. and Symon, G. (Eds.), Essential Guide to Qualitative Methods in Organizational Research, Sage, London, pp. 256-270.

Konopaske, R. and Werner, S. (2005), “US managers' willingness to accept a global assignment: Do expatriate benefits and assignment length make a difference?", The International Journal of Human Resource Management, Vol. 16 No. 7, pp. 1159-1175.

Lazarova, M., Westman, M. and Shaffer, M.A. (2010), "Elucidating the positive side of the work-family interface on international assignments: A model of expatriate work and family performance”, Academy of Management Review, Vol. 35 No. 1, pp. 93-117. 
Mayerhofer, H., Hartmann, L.C., Michelitsch-Riedl, G. and Kollinger, I. (2004), "Flexpatriate assignments: A neglected issue in global staffing", The International Journal of Human Resource Management, Vol. 15 No. 8, pp. 1371-1389.

Mayrhofer, W. and Scullion, H. (2002), "Female expatriates in international business: Empirical evidence from the German clothing industry", The International Journal of Human Resource Management, Vol. 13 No. 5, pp. 815-836.

McNulty, Y., De Cieri, H. and Hutchings, K. (2013), "Expatriate return on investment in the Asia Pacific: An empirical study of individual ROI versus corporate ROI", Journal of World Business, Vol. 48 No. 2, pp. 209-221.

Melkas, H. and Anker, R. (2001), “Occupational segregation by sex in Nordic countries: An empirical investigation”, in Loutfi, M.F. (Ed.), Women, Gender and Work: What is Equality and How Do We Get There?, International Labour Organization , Geneva, pp. 189-213.

Millar, J. (1999), “Obligations and autonomy in social welfare”, in Crompton, R. (Ed.), Restructuring Gender Relations and Employment: The Decline of the Male Breadwinner, Oxford University Press, Oxford, pp. 26-39.

Morley, M.J., Heraty, N. and Collings, D.G. (2006), "Introduction: New directions in expatriate research", in Morley, M.J., Heraty, N. and Collings, D.G. (Eds.), New Directions in Expatriate Research, Palgrave Macmillan, Basingstoke, pp. 1-17).

ORC Worldwide. (2007), 2006 Worldwide Survey of International Assignment Policies and Practices, ORC Worldwide, New York, NY.

Pate, J. and Scullion, H. (2010), “The changing nature of the traditional expatriate psychological contract”, Employee Relations, Vol. 32 No. 1, pp. 56-73. 
Perkins, S.J. and Shortland, S.M. (2006), Strategic International Human Resource Management: Choices and Consequences in Multinational People Management, Kogan Page, London.

Perkins, S.J. and White, G. (2009), Employee reward. Alternatives, Consequences and Contexts, CIPD, London.

Permits Foundation. (2012), International Mobility and Dual Career Survey of International Employers, Permits Foundation, The Hague.

Pinto, L.H., Cabral-Cardoso, C. and Werther, W.B. (2012), “Compelled to go abroad? Motives and outcomes of international assignments", The International Journal of Human Resource Management, Vol. 23 No. 11, pp. 2295-2314.

Powell, A., Bagilhole, B., Dainty, A. and Neale, R. (2004), "Does the engineering culture in UK higher education advance women's careers?", Equal Opportunities International, Vol. 23 No. 7/8, pp. 21-38.

Punnett, B.J., Crocker, O. and Stevens, M.A. (1992), “The challenge for women expatriates and spouses: Some empirical evidence", The International Journal of Human Resource Management, Vol. 3 No. 3, pp. 585-592.

Richardson, J., McKenna, S. and Dickie, C. (2014), ““‘'They always look at you a bit oddly": Women developing career capital through international mobility in the mining industry", in Hutchings, K. and Michailova, S. (Eds.), Research Handbook on Women in International Management, Edward Elgar, Cheltenham, pp. 367-394.

Rosen, S. (1986), “The theory of equalizing differences”, in Ashenfelter, O. and Layard, R. (Eds.), Handbook of Labor Economics, Volume 1, Elsevier Science Publishers B.V., Amsterdam, pp. 641-692. 
Scullion, H. and Brewster, C. (2001), "The management of expatriates: Messages from Europe?", Journal of World Business, Vol. 36 No. 4, pp. 346-365.

Shaffer, M., Singh, B. and Chen, Y.-P. (2013), "Expatriate pay satisfaction: The role of organizational inequities, assignment stressors and perceived assignment value", The International Journal of Human Resource Management, Vol. 24 No. 15, pp. 2968-2984.

Shankaran, G., Murray, R.A. and Miller, P. (2011), "Short-term international assignments: Maximizing effectiveness, minimizing cost and risk”, International Tax Journal, No. January-February, pp. 41-60.

Shortland, S. and Altman, Y. (2011), "What do we really know about corporate career women expatriates?", European Journal of International Management, Vol. 5 No. 3, pp. 209234.

Shortland, S. (2014a), "Role models: Expatriate gender diversity pipeline or pipedream?”, Career Development International, Vol. 19 No. 5, pp. 572-594.

Shortland, S. (2014b), "Women expatriates: A research history", in Hutchings, K. and Michailova, S. (Eds.), Research Handbook on Women in International Management, Edward Elgar, Cheltenham, pp 18-44.

Shortland, S. and Perkins, S.J. (2016), "Long-term assignment reward (dis)satisfaction outcomes: Hearing women's' voices”, Journal of Global Mobility, Vol. 4 No. 2, pp. 225-250.

Stroh, L.K., Varma, A. and Valy-Durbin, S. J. (2000), "Women and expatriation: Revisiting Adler's findings", in Davidson, M.J. and Burke, R.J. (Eds.), Women in Management, Sage, London, pp.104-119.

Suutari, V. and Tornikoski, C. (2001), "The challenge of expatriate compensation: The sources of satisfaction and dissatisfaction among expatriates", The International Journal of Human Resource Management, Vol. 12 No. 3, pp. 389-404. 
Suutari, V., Tornikoski, C. and Mäkelä, L. (2012), “Career decision making of global careerists", The International Journal of Human Resource Management, Vol. 23 No. 16, pp. 3455-3478.

Tharenou, P. (2009), "Self-initiated international careers: Gender differences and career outcomes", in Baugh, S.G, and Sullivan, S.E. (Eds.), Maintaining Focus, Energy, and Options over the Career, Information Age Publishing, Charlotte, NC, pp. 198-226.

Tornikoski, C. (2011a), "Fostering expatriate affective commitment: A total reward perspective”, Cross Cultural Management, Vol. 18 No. 2, pp. 214-235.

Tornikoski, C. (2011b), “Expatriate compensation: A theoretical approach”, in Antoni, C.H., Baeten, X., Lucas, R., Perkins, S. and Vartiainen, M. (Eds.), Pay and Reward System in Organizations - Theoretical Approaches and Empirical Outcomes, Pabst Science Publishers, Lengerich, pp. 38-67.

Tung, R.L. (2004), “Female expatriates: The model global manager”, Organizational Dynamics, Vol. 33 No. 3, pp. 243-252.

van der Velde, M.E.G., Bossink, C.J.H. and Jansen, P.G.W. (2005), “Gender differences in the determinants of the willingness to accept an international assignment", Journal of Vocational Behavior, Vol. 66 No. 1, pp. 81-103.

Wagner, M.R. and Westaby, J.D. (2009), “The willingness to relocate to another country: The impact of cultural similarity, destination safety, and financial incentive", The International Journal of Psychology, Vol. 44 No 4, pp. 257-265.

Warneke, D. and Schneider, M. (2011), "Expatriate compensation packages: What do employees prefer?", Cross Cultural Management: An International Journal, Vol. 18 No. 2, pp. $236-256$. 
Welch, D.E., Welch, L.S. and Worm, V. (2007), “The international business traveller: A neglected but strategic human resource", The International Journal of Human Resource Management, Vol. 18 No 2, pp. 173-183.

Wilton, N. and Purcell, K. (2010), "The impact of partnership and family-building on the early careers of female graduates in the UK", Equality, Diversity and Inclusion: An International Journal, Vol. 29 No. 3, pp. 271-288.

Yanadori, Y. (2011), "Paying both globally and locally: An examination of the compensation management of a US multinational finance firm in the Asia Pacific region", The International Journal of Human Resource Management, Vol. 22 No. 18, pp. 3867-3887. 
Table 1: Profile of assignees interviewed

\begin{tabular}{|c|c|c|c|c|c|}
\hline $\begin{array}{c}\text { Participant } \\
\text { number } \\
\text { and company }\end{array}$ & $\begin{array}{c}\text { Current assignment } \\
\text { type }\end{array}$ & $\begin{array}{l}\text { Previous } \\
\text { assignment type(s) } \\
\text { with current firm }\end{array}$ & Home region & $\begin{array}{c}\text { Host region } \\
\text { (current assignment) }\end{array}$ & $\begin{array}{c}\text { Family status } \\
\text { (current assignment) }\end{array}$ \\
\hline \multicolumn{6}{|c|}{ Flexpatriate Experience } \\
\hline \#59, Co. A & Rotation & & Western Europe & North Africa & Married/partnered, unaccompanied, no children \\
\hline \#26, Co. B & Rotation & & Australasia & Central Asia & Married/partnered, unaccompanied, no children \\
\hline \#52, Co. B & Rotation & Short-term & Western Europe & Central Asia & Married/partnered, unaccompanied, no children \\
\hline$\# 69$, Co. A & Long-term & Rotation & North America & Western Europe & Divorced/widowed, unaccompanied, two children \\
\hline \#17, Co. B & Long-term & Rotation & Western Europe & Middle East & Married/partnered, accompanied, no children \\
\hline \#3, Co. B & Short-term & & Western Europe & North America & Married/partnered, unaccompanied, no children \\
\hline \#25, Co. B & Short-term & Short-term & Western Europe & East Asia & Single, unaccompanied, no children \\
\hline \#10, Co. B & Long-term & Long-term; Short-term & Western Europe & Australasia & Married/partnered, unaccompanied, no children \\
\hline \#24, Co. B & Long-term & Short-term & Western Europe & Western Europe & Married/partnered, accompanied, one child \\
\hline \#46, Co. B & Long-term & Long-term; Short-term & Western Europe & East Asia & Married/partnered, accompanied, two children \\
\hline \#33, Co. B & Long-term & Commuter & Western Europe & Australasia & Married/partnered, accompanied, no children \\
\hline \multicolumn{6}{|c|}{ Long-term Assignment Experience Only } \\
\hline \#56, Co. A & Long-term & & Western Europe & East Asia & Married/partnered, accompanied, one child \\
\hline \#57, Co. A & Long-term & Long-term & North America & Central Asia & Divorced/widowed, , unaccompanied, no children \\
\hline \#60, Co. A & Long-term & Long-term & Western Europe & East Asia & Married/partnered, accompanied, one child \\
\hline \#62, Co. A & Long-term & & East Asia & Western Europe & Single, unaccompanied, no children \\
\hline \#63, Co. A & Long-term & Long-term & North America & East Asia & Married/partnered, accompanied, no children \\
\hline \#65, Co. A & Long-term & Long-term & East Asia & North America & Single, unaccompanied, no children \\
\hline$\# 2$, Co. B & Long-term & Long-term & Western Europe & Caribbean & Married/partnered, accompanied, three children \\
\hline$\# 5$, Co. B & Long-term & & Australasia & West Africa & Married/partnered, accompanied, no children \\
\hline$\# 14$, Co. B & Long-term & Long-term & Western Europe & Central Asia & Married/partnered, accompanied, no children \\
\hline \#20, Co. B & Long-term & & Western Europe & Australasia & Married/partnered, accompanied, no children \\
\hline \#35, Co. B & Long-term & Long-term & Western Europe & North Africa & Married/partnered, accompanied, one child \\
\hline$\# 39$, Co. B & Long-term & Long-term & Western Europe & North Africa & Married/partnered, accompanied, one child \\
\hline \#44, Co. B & Long-term & & Caribbean & North America & Married/partnered, accompanied, one child \\
\hline$\# 45$, Co. B & Long-term & Long-term & Caribbean & West Africa & Single, unaccompanied, no children \\
\hline$\# 50$, Co. B & Long-term & & Western Europe & Central Asia & Married/partnered, unaccompanied, no children \\
\hline
\end{tabular}


Figure 1: A model to depict women expatriate breadwinners' compensation and benefits deal makers

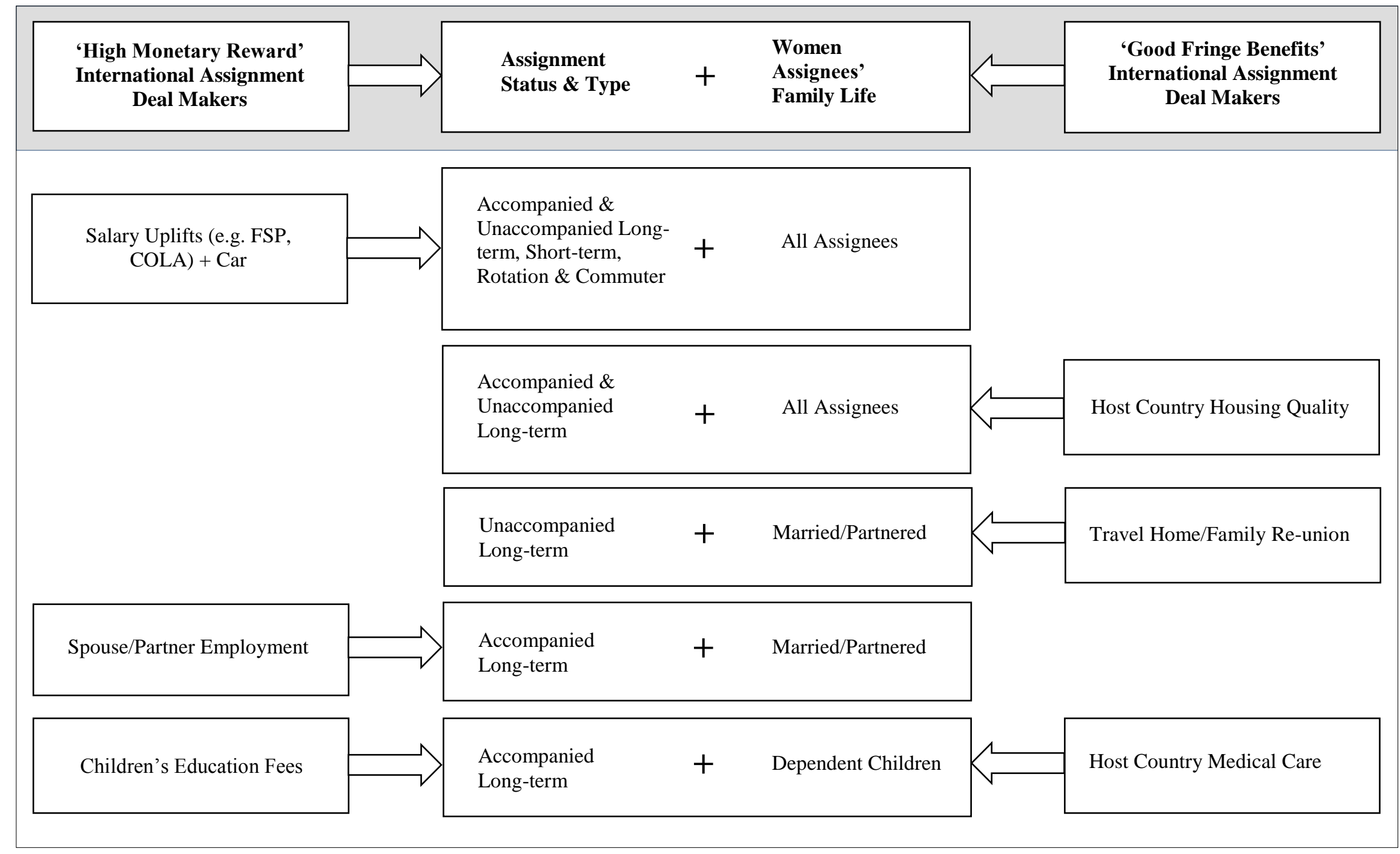

